\title{
Publishers challenged over access to papers
}

\section{Meredith Wadman, Washington}

A battle over access to biomedical research papers was no closer to a resolution this week, after two leading journals said they would make their papers freely available on the web within a year of initial publication.

Scientific publishers and some biomedical researchers have been arguing for a couple of years now about the circumstances in which papers should be made available on the Internet. Early last year, the US National Institutes of Health (NIH) introduced a forum called PubMedCentral on which journals can deposit their contents, but few leading journals have chosen to participate.

Now, a group of researchers say they will stop buying, publishing in or reviewing for any journal that refuses to place its research papers in a proposed Public Library of Science (PLS) within six months of their initial publication.

Publishers say that free access could leave journals without enough revenue to support editing or peer review. They have also warned that the proposed PLS might, in effect, bring biomedical publishing under the control of the US government, raising problems about political control and international acceptance.

Science said in an editorial last Friday (23 March) that it will make its content freely available on its website a year after publication, and the Journal of Cell Biology said it would do the same after six months.

Donald Kennedy, the editor of Science, which is published by the American Association for the Advancement of Science, says of free access: "A lot of people agree that basically this is a good idea. The question is, how can an array of journals do this without exposing

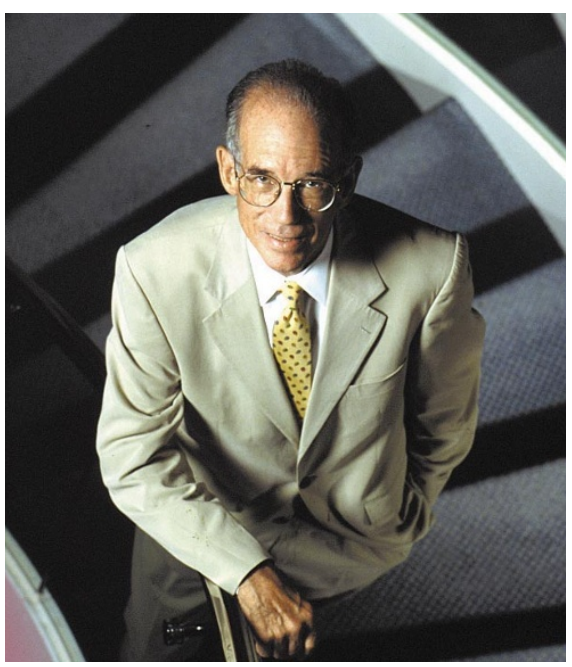

Controlling interests: Science's Donald Kennedy warns of a 'tax supported central monopoly'.

themselves to serious economic risk?"

By 27 March, 12,095 scientists had signed an online petition calling for the establishment of the PLS. The signatories, who include many prominent molecular biologists, pledge to begin their boycott in September. Their leaders include Pat Brown, a geneticist at Stanford University, and Harold Varmus, the former director of the $\mathrm{NIH}$, who is president of Memorial SloanKettering Cancer Center in New York.

The initiative's leaders contend that efficient searching is as important as free access, and so the new policies announced by Science and $J C B$, while welcome, still fall short. They say they want to see a competing set of public and private databases, at any one of which scientists could find most of the literature.

But publishers think that the actual impact

\section{Butchery lay behind CJD cluster}

\section{David Adam, London}

Traditional butchery practices are the most likely cause of Britain's first cluster of variant Creutzfeldt-Jakob disease (vCJD) in the Leicestershire village of Queniborough, an official public health report concluded last week. The investigation into the deaths of five people from vCJD, the human form of BSE, also pins down the estimate of the disease's incubation period to between 10 and 16 years.

The inquiry team believes that the disease was probably spread as butchers split open the heads of infected cow carcasses to remove brain tissue, which can contain the BSE agent. This could have allowed the sticky, tainted tissue to be transferred to other cuts of meat from knives, hands, slabs and aprons. Removing brain tissue was popular during the Second World War as a cheap source of protein, but the practice was relatively rare in Britain during the 1980s and has since been banned.

Four of the five victims ate beef bought from one of two butchers who either slaughtered animals and removed the brains themselves or used a small, local abattoir during the first half of the 1980s, the inquiry found.

But Robert Will, director of the UK National CJD Surveillance Unit, says that the low number of cases involved makes it difficult to make more general predictions from this cluster. "These may be early incubation periods so what really matters is the mean period," he says, adding that other cases of vCJD will almost certainly appear after much longer periods of time.

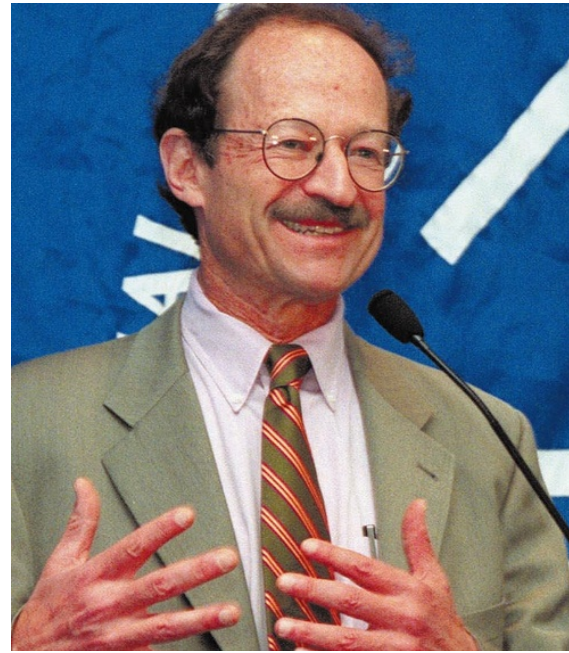

Free for all: Harold Varmus believes publishers are holding on to content they should release.

of the initiative would be to place the entire biomedical literature in one public database - probably PubMedCentral, which was launched at the NIH under Varmus. "One has to ask oneself whether a private site is going to arise to compete with an already-established, already-populated, fully-tax-supported central monopoly," says Kennedy. "That doesn't happen very often in the real world."

Varmus responds: "Nobody is arguing for a monopoly here. The only monopoly I see is what seems to be an attempt by journals to hold onto content that at a certain point they should let go."

Some of the loudest complaints about the PLS proposal are coming from scientific societies that rely heavily on journals for income. They say that they will be disproportionately hit by the threatened boycott. "[Commercial scientific publisher] Reed-Elsevier is probably sitting there chortling 'Let the society publishers go out of business," says Martin Frank, the executive director of the American Physiological Society, which publishes 14 journals. "They've got deep enough pockets to say: 'To hell with this boycott."

Annette Thomas, managing director of the Nature Publishing Group, says that the group welcomes discussion of the issue with researchers. "Many complex issues have been raised and we are currently soliciting feedback from scientists, librarians and other interested parties," she says.

Derk Haank, chief executive officer of Elsevier, says: "We are looking at the issue but our concern is that there must be an acceptable business model."

But Bruce Alberts, the president of the US National Academy of Sciences, suggests that journals can post free back-content relatively promptly without undue financial risk. "Six months or a year should be safe for any journal," he says. 